\title{
HUBUNGAN KONSEP DIRI SISWA DENGAN PROSOSIAL SISWA DI SMAN 1 LUBUK SIKAPING
}

\author{
Suci Intan Rahayu ${ }_{\text {Email : firman@konselor.org }}^{\text {firman }}{ }^{2)}$, Yarmis Syukur ${ }^{3)}$
}

\begin{abstract}
Prosocial behaviour is influenced by several factors, one of which was the concept of the self. When students look at and assess their positive then the student will display the prososial behaviour in daily life. This research aims to look at the description of the concept of self and prosocial students and reveals how the relationships between the concepts of self and prososial SMAN 1 Lubuk Sikaping students. This research is descriptive research correlational. Research population totaled 574 people SMAN 1 Lubuk Sikaping, class XI and XII listed school year 2014/2015, with a sample of 85 people taken using techniques Proportionate Stratified Random Sampling. Data collection using question form on the concepts of self and prosocial. The Data obtained were analyzed by using statistical methods and looking for a score, the percentage of gains (\%) score and the ideal's score. To see the relationship of self concept of prosocial behaviour with student data processed by using Microsoft Office Programs Excel and SPSS program for windows release 16.0. Research findings show that there were significant positive relationships between the concepts themselves by prosocial SMAN 1 Lubuk Sikaping students.
\end{abstract}

Keywords: Self-Concept, Prosocial Behaviour

\section{PENDAHULUAN}

Dalam proses pendidikan, setiap peserta didik juga mengembangkan kemampuan sosialnya sebagai makhluk sosial dengan cara berinteraksi dan bersosialisasi dengan lingkungannya. Sebagaimana yang diungkapkan Bimo Walgito (2003:25) bahwa: "Pada hakikatnya manusia adalah makhluk sosial yang mempunyai dorongan untuk berinteraksi dengan individu lain didalam masyarakat". Melalui interaksi individu dapat mempengaruhi tingkah laku, perbuatan, pikiran, sikap, dan perasaan orang lain. Salah satu bentuk interaksi sosial adalah perilaku prososial.

Perilaku prososial adalah segala tindakan atau rangsangan terhadap lingkungan atau situasi tertentu yang dapat memberikan keuntungan baik secara langsung atau pun tidak langsung bagi orang lain yang menjadi objek. Sebagaimana yang dikemukakan oleh Twenge, dkk. (dalam Agus Abdul Rahman, 2012:209) bahwa perilaku prososial adalah tindakan yang menguntungkan orang lain atau masyarakat secara umum.

Namun pada saat sekarang ini, perilaku prososial telah semakin berkurang dikalangan remaja khususnya siswa siswi di sekolah, seperti fenomena yang tampak di SMAN 1 Lubuk Sikaping yang juga merupakan salah satu sekolah favorit di Kabupaten Pasaman.

Berdasarkan hasil wawancara peneliti dengan beberapa orang siswa (inisial: DN, IK, SC, WD) yang dilaksanakan pada hari Senin dan Selasa tanggal 2 \& 3 Juni 2014, diperoleh informasi bahwa ada siswa di sekolah tersebut yang memilih-milih teman dalam menolong dan hanya mau menolong

\footnotetext{
${ }^{1}$ Suci Intan Rahayu (1), Jurusan Bimbingan dan Konseling, Fakultas Ilmu Pendidikan, Universitas Negeri Padang, email: cintra92.SIR@gmail.com

${ }^{2}$ Firman (2), Jurusan Bimbingan dan Konseling, Fakultas Ilmu Pendidikan, Universitas Negeri Padang

${ }^{3}$ Yarmis Syukur (3), Jurusan Bimbingan dan Konseling, Fakultas Ilmu Pendidikan, Universitas Negeri Padang
} 
siswa yang dekat atau satu kelompok pertemanan (genk) dengan mereka.

Fenomena lain, ketika guru memberikan tugas kelompok kepada siswa, kebanyakan yang terjadi adalah hanya satu atau dua orang siswa yang akan mengerjakan tugas tersebut, sedangkan yang lain sibuk

\footnotetext{
${ }^{1}$ Suci Intan Rahayu (1), Jurusan Bimbingan dan Konseling, Fakultas Ilmu Pendidikan, Universitas Negeri Padang, email: cintra92.SIR@gmail.com

${ }^{2}$ Firman (2), Jurusan Bimbingan dan Konseling, Fakultas Ilmu Pendidikan, Universitas Negeri Padang

${ }^{3}$ Yarmis Syukur (3), Jurusan Bimbingan dan Konseling, Fakultas Ilmu Pendidikan, Universitas Negeri Padang
} 
dengan kegiatan masing-masing, tidak ada rasa kerja sama dan sikap saling membantu antar anggota kelompok. Bahkan hal kecil seperti masih banyaknya siswa yang menertawakan atau mencemooh teman yang tidak sengaja melakukan kesalahan pun masih banyak sekali terjadi.

Namun, tinggi rendahnya prososial remaja tidak hanya terjadi begitu saja, berbagai faktor dapat mempengaruhiperilaku prososial, salah satunya adalah konsep diri, sejalan dengan pendapat Sarlito Sarwono dan Eko Meinarno (2009:57) yang mengungkapkan bahwa tingkah laku sosial seseorang dipengaruhi oleh pengetahuan tentang siapa dirinya. Menurut Alex Sobur (2011:507), konsep diri adalah "Semua persepsi kita terhadap aspek diri yang meliputi aspek fisik, aspek sosial, dan aspek psikologis, yang didasarkan pada pengalaman dan interaksi kita dengan orang lain".

Konsep diri dapat menjadi salah satu faktor dalam pembentukan perilaku yang ditampilkan oleh remaja, sebagaimana yang diungkapkan Elida Prayitno (2006:125) bahwa konsep diri dapat digunakan sebagai penentu tingkah laku. Berkaitan dengan ini, peneliti juga melakukan wawancara terhadap siswa SMAN 1 Lubuk Sikaping lainnya (IN \& AL) hari Kamis tanggal 4 Juni 2014. Mereka mengatakan "saya bersekolah di sekolah unggul dan persaingannya ketat" dan "saya ingin mendapatkan nilai yang lebih bagus dari teman-teman yang lain, jika saya mengajarkan mereka materi yang saya dapatkan di tempat les maka nilai mereka juga akan tinggi seperti saya". Oleh sebab itu berdasarkan beberapa fenomena-fenomena yang terjadi, peneliti tertarik ingin meneliti lebih lanjut tentang Hubungan Konsep Diri dengan Prososial Siswa di SMAN 1 Lubuk Sikaping".

Rumusan masalah penelitian ini adalah bagaimana hubungan konsep diri dengan prososial siswa di SMAN 1 Lubuk Sikaping. Tujuan penelitian ini adalah; 1) Mendeskripsikan konsep diri siswa, 2) Mendeskripsikan prososial siswa , 3) Untuk mengungkap hubungan konsep diri dengan prososial siswa di SMAN 1 Lubuk Sikaping.

\section{METODOLOGI PENELITIAN}

Penelitian ini jenisnya deskriptif korelasional, yaitu penelitian yang menggambarkan suatu keadaan atau situasi tertentu sebagaimana adanya secara sistematis dan akurat, serta menetukan hubungan antara variabel yang akan diteliti.

Populasi penelitian adalah siswa SMAN 1 Lubuk Sikaping kelas XI dan XII sebanyak 574 siswa dan sampel penelitian sebanyak 85 siswa. Alat pengumpulan data menggunakan angket. Untuk setiap kemungkinan jawaban angket penelitian memiliki 5 kemungkinan pilihan jawaban yaitu: Sangat Sesuai (SS), Sesuai (S), Cukup Sesuai (CS) jika, Kurang Sesuai (KS), Tidak Sesuai (TS). Teknik analisis data menggunakan skor ideal dan rumus pencarian persen (\%) skor. Untuk melihat tingkat hubungan antar kedua variabel, peneliti menggunakan rumus Pearson Product Moment Correlation yang dikemukakan Riduwan (2009:136) melalui program statistik SPSS for windows release 16.0.

\section{HASIL PENELITIAN}

\section{Konsep Diri dan Prososial Siswa SMAN 1 Lubuk Sikaping}

Tabel 1

Skor Ideal (SI), Skor tertinggi (ST) dan Skor terendah (SR) dan Mean Konsep Diri dan

Prososial Siswa $(\mathbf{n}=\mathbf{8 5})$

\begin{tabular}{|c|l|c|c|c|c|}
\hline No & Variabel & SI & ST & SR & Mean \\
\hline $\mathbf{1}$ & Konsep Diri & 225 & 190 & 46 & 133,8 \\
\hline $\mathbf{2}$ & Prososial & 225 & 216 & 47 & 142,7 \\
\hline
\end{tabular}

Pada tabel 1, diketahui skor ideal variabel konsep diri adalah 225, skor tertinggi yang berhasil dicapai responden adalah 190 dan skor terendahnya 46, dengan nilai mean sebesar 133,8. Sedangkan untuk variabel prososial, skor idealnya 225, skor tertinggi yang berhasil dicapai responden adalah 216 , dan skor 
terendahnya 47, dengan nilai mean sebesar 142,7.

Tabel 2

Konsep Diri dan Prososial Siswa SMAN 1 Lubuk Sikaping

$$
\mathbf{n}=\mathbf{8 5}
$$

\begin{tabular}{|c|c|c|c|c|c|c|c|c|c|c|c|c|c|}
\hline \multirow{3}{*}{ Aspek } & \multicolumn{10}{|c|}{ Kategori } & \multicolumn{3}{|c|}{ Rata-rata } \\
\hline & \multicolumn{2}{|c|}{$\begin{array}{l}\text { Sangat } \\
\text { Positif }\end{array}$} & \multicolumn{2}{|c|}{ Positif } & \multicolumn{2}{|c|}{$\begin{array}{l}\text { Cukup } \\
\text { Positif }\end{array}$} & \multicolumn{2}{|c|}{$\begin{array}{l}\text { Tidak } \\
\text { Positif }\end{array}$} & \multicolumn{2}{|c|}{$\begin{array}{c}\text { Sangat } \\
\text { Tidak } \\
\text { Positif } \\
\end{array}$} & Skor & $\%$ & $\begin{array}{l}\text { Kate } \\
\text { gori }\end{array}$ \\
\hline & $f$ & $\%$ & $\mathrm{f}$ & $\%$ & $\mathrm{f}$ & $\%$ & $\mathrm{f}$ & $\%$ & $\mathrm{f}$ & $\%$ & & & \\
\hline Fisik & 8 & 9 & 28 & 33 & 18 & 21 & 19 & 23 & 12 & 14 & 3,01 & 60 & $\begin{array}{l}\text { Cukup } \\
\text { Positif }\end{array}$ \\
\hline Emosi & 2 & 2 & 23 & 27 & 19 & 22 & 32 & 38 & 9 & 11 & 2,73 & 55 & $\begin{array}{l}\text { Cukup } \\
\text { Positif }\end{array}$ \\
\hline Moral & 13 & 1 & 27 & 32 & 12 & 14 & 26 & 31 & 7 & 8 & 3,51 & 70 & Positif \\
\hline Sosial & 10 & $\begin{array}{l}1 \\
2 \\
2\end{array}$ & 25 & 29 & 15 & 18 & 28 & 33 & 7 & 8 & 3,04 & 61 & $\begin{array}{l}\text { Cukup } \\
\text { Positif }\end{array}$ \\
\hline $\begin{array}{l}\text { Kognit } \\
\text { if }\end{array}$ & 0 & 0 & 16 & $\begin{array}{ll}19 \\
\end{array}$ & 31 & 37 & 30 & 35 & 8 & 9 & 2,65 & 53 & $\begin{array}{l}\text { Cukup } \\
\text { Positif }\end{array}$ \\
\hline
\end{tabular}

Tabel 2 menggambarkan konsep diri dan prososial siswa di SMAN 1 Lubuk Sikaping. Pada variabel konsep diri, terdapat 35 orang siswa SMAN 1 Lubuk Sikaping berada pada kategori positif dengan persentase $41 \%$. Selanjutnya pada kategori tidak positif terdapat 30 orang siswa dengan persentase $35 \%$. Sedangkan di kategori cukup positif sebanyak 14 orang siswa dengan persentase $17 \%$ dan 6 orang siswa yang berada di kategori sangat tidak positif dengan persentase 7\%. Temuan ini menggambarkan bahwa pencapaian konsep diri siswa SMAN 1 Lubuk Sikaping rata-rata berada pada kategori cukup positif dengan persentase sebesar $41 \%$.

Pada variabel prososial, terdapat 14 orang siswa SMAN 1 Lubuk Sikaping yang prososialnya tergolong sangat baik dengan persentase $17 \%$. Selanjutnya pada kategori baik terdapat 29 orang siswa dengan persentase $34 \%$, pada kategori cukup baik terdapat 8 orang siswa dengan persentase 9\%. Sedangkan pada kategori kurang baik terdapat 28 siswa dengan persentase 33\% dan 6 orang siswa berada pada kategori tidak baik dengan persentase 7\%. Temuan ini menggambarkan bahwa pencapaian prososial siswa SMAN 1 Lubuk Sikaping terbanyak rata-rata pada kategori cukup baik dengan persentase sebesar 34\%.

\section{Hubungan Konsep Diri Dengan Prososial Siswa Di SMAN 1 Lubuk Sikaping}

Tabel 3

Hasil Uji Hipotesis Hubungan Konsep Diri dengan Prososial Siswa

$\mathrm{n}=85$

\begin{tabular}{|l|l|l|l|l|}
\hline Variabel & \multicolumn{1}{|r|}{$\begin{array}{c}\text { r } \\
\text { hitung }\end{array}$} & $\begin{array}{c}\text { T } \\
\text { table }\end{array}$ & $\begin{array}{c}\text { Tingkat } \\
\text { keeratan }\end{array}$ & $\begin{array}{l}\text { Kesimpul } \\
\text {-an }\end{array}$ \\
\hline $\begin{array}{l}\text { Konsep } \\
\text { Diri } \\
\&\end{array}$ & 0,996 & 0,278 & $\begin{array}{l}\text { Sangat } \\
\text { Kuat }\end{array}$ & $\begin{array}{l}\mathrm{H}_{\mathrm{o}} \\
\text { diterima }\end{array}$ \\
$\begin{array}{l}\text { Prososial } \\
\text { Siswa }\end{array}$ & & & & \\
\hline
\end{tabular}

Berdasarkan tabel 3, diketahui $r_{\text {hitung }}>$ $r_{\text {tabel }}(0,996>0,278)$ sehingga dapat ditarik kesimpulan terdapat hubungan yang signifikan positif antara konsep diri dengan prososial siswa SMAN 1 Lubuk Sikaping, artinya semakin positif konsep diri siswa maka semakin baik pula tingkah laku prososial siswa demikian sebaliknya semakin negatif konsep diri siswa maka semakin kurang baik pula tingkah laku prososialnya, dengan interpretasi koefisien korelasi memiliki tingkat hubungan yang sangat kuat.

\section{PEMBAHASAN}

\section{Konsep Diri Siswa}

a. Bentuk Umum Konsep Diri Siswa di SMAN 1 Lubuk Sikaping

Menurut William D. Brook (dalam Alex Sobur, 2003: 507), konsep diri dapat didefenisikan sebagai persepsi fisik, sosial dan psikologis dari diri individu yang berasal dari pengalaman dan interaksinya dengan orang lain.

Hasil penelitian menunjukkan rata-rata siswa SMAN 1 Lubuk Sikaping memiliki konsep diri yang cukup positif dengan persentase sebesar 58\%. Hal ini menandakan bahwa rata-rata siswa SMAN 1 Lubuk Sikaping memiliki persepsi, penilaian dan sudut pandang yang cukup positif terhadap diri mereka sendiri.

Masa remaja merupakan masa transisi antara kehidupan kanak-kanak dan 
kehidupan orang dewasa. Masa remaja juga merupakan masa pencarian identitas diri. Oleh karena itu remaja harus memiliki keyakinan hidup yang benar untuk mengarahkan mereka dalam bertingkahlaku. Pada masa remaja ini, manusia akan mengalami berbagai perubahan, baik dari segi fisik maupun psikis. Jika remaja tidak mampu berhadapan dan mengatasi tantangan perubahan ini secara sukses, akan muncul konsekuensi psikologis, emosional dan behavioral yang merugikan dan sangat mempengaruhi pemikiran, persepsi dan sudut pandangnya kepada diri sendiri dan juga lingkungan sekitarnya. Pada berbagai konsekuensi inilah, bimbingan dan konseling bisa sangat berguna dalam mengatasinya.

Peranan konselor/guru BK akan sangat membantu jika konselor/guru BK turut aktif dalam mengembangkan perannya berupa kegiatan dalam membimbing remaja menemukan identitas dan jati dirinya dan sehingga terbebas dari konsekuensi negatif dalam melalui perubahan yang ada dalam kehidupannya dan mampu memiliki pandangan dan penilaian yang positif baik terhadap dirinya maupun orang lain di sekitarnya.

\section{b. Konsep Diri Siswa di SMAN 1 Lubuk Sikaping Pada Setiap Aspek \\ 1) Fisik}

Konsep diri siswa di SMAN 1 Lubuk Sikaping pada aspek fisik berada pada kategori positif dengan persentase sebesar 33\%. Dapat dikatakan bahwa konsep diri dari aspek fisik yang dimiliki oleh siswa sudah baik, sebagian siswa sudah mampu menilai dan mempersepsikan fisik dan keadaan dirinya dengan positif.

Diharapkan guru BK di sekolah menyusun program pelayanan BK yang dapat menumbuhkan dan mengembangkan konsep diri siswa dalam aspek fisik. Berbagai cara dapat dilakukan seperti mengembangkan program kelompok remaja kearah kegiatan yang bernilai positif seperti olahraga, pramuka, dan seni. Disamping itu, guru BK perlu membantu remaja agar memahami keadaan fisik dan perubahan-perubahan yang terjadi pada dirinya serta masalah yang berkaitan dengan perubahan tersebut. Kegiatan pelayanan BK dalam bidang pengembangan pribadi dan sosial dapat dilakukan seperti layanan informasi, penguasaan konten, kegiatan bimbingan \& konseling kelompok serta konseling individual. Sehingga konsep diri siswa yang telah baik dapat dipertahankan dan konsep diri siswa yang masih belum baik dapat dikembangkan ke arah yang lebih positif.

\section{2) Emosi}

Konsep diri siswa SMAN 1 Lubuk Sikaping dilihat dari segi emosi berada pada kategori tidak positif dengan persentase 38\%. Menurut Mudjiran, dkk. (2002: 95) emosi dapat diartikan sebagai suatu reaksi psikologis yang ditampilkan dalam bentuk tingkah laku gembira, bahagia, sedih, berani, takut, marah, muak, cinta, dan sebagainya. Dalam hal ini dapat dikatakan bahwa pada umumnya siswa SMAN 1 Lubuk Sikaping menilai dan memiliki sudut padang bahwa mereka tidak mampu menampilkan emosi yang positif dalam kehidupan sehari-harinya.

Peran guru BK dalam mengembangkan konsep diri siswa dalam aspek emosi pada dasarnya sangat diperlukan, mengingat tingginya kecenderungan gejolak emosi yang terjadi pada saat remaja. Jika remaja tidak mampu menyesuaikan diri dengan masa transisinya, kemungkinan munculnya emosi negatif sangat besar. Gangguan emosi yang terjadi akan berdampak kepada cara remaja menampilkan perilakunya. Untuk itu guru BK perlu membantu siswa dalam mengembangkan emosi positif dalam diri siswa dengan mengembangkan program pelayanan $\mathrm{BK}$ dalam bidang pribadi dan sosial seperti diadakannya program latihan beremosi, misalnya dalam merespon dan menyikapi sesuatu yang tidak berjalan sebagaimana mestinya. Selain itu guru BK hendaknya mampu menjadi model dalam mengekspresikan emosi negatif, sehingga tampilannya tidak 
meledak-ledak dan merugikan diri sendiri maupun orang lain.

\section{3) Moral}

Berdasarkan hasil penelitian, konsep diri siswa dari segi moral di SMAN 1 Lubuk Sikaping berada pada kategori positif dengan persentase $32 \%$. Dapat disimpulkan bahwa sebagian siswa telah memiliki seperangkat nilai atau sistem etis untuk menjadi pedoman dalam bertingkahlaku serta menjalani kehidupan bermasyarakat.

Santrock dan Yusan (dalam Mudjiran, 2002: 110) mengemukakan bahwa moral adalah kebiasaan atau aturan yang harus dipatuhi seseorang dalam berinteraksi dengan orang lain. Siswa yang memiliki moral yang tinggi cenderung berpikiran positif dan menampilkan perilaku yang positif pula dalam berinteraksi dengan orang lain. Namun sebaliknya, siswa yang tidak mampu memahami nilai dan aturan yang harus dilaksanakan atau harus dihindari, akan menampilkan perilaku yang negatif.

Peranan guru BK sangatlah penting dalam pembentukan moral siswa. Siswa akan berkembang moralnya dengan baik apabila ia dapat meniru orang lain dilingkungannya betingkahlaku moral, dan sekaligus dilatih melakukan tingkah laku. Untuk itu, guru BK diharapkan mampu menjadi contoh dalam bertingkah laku sesuai dengan tuntutan nilai moral yang berlaku. Selain itu guru BK hendaknya menyusun program pelayanan BK yang mana dalam pelaksanaannya terkandung nilai-nilai moral, seperti layanan informasi tentang segala sesuatu yang berkaitan dengan moral untuk membentuk pandangan moral dan tingkah laku-tingkah laku siswa yang bermoral.

\section{4) Sosial}

Selanjutnya, konsep diri siswa SMAN 1 Lubuk Sikaping jika dilihat dari aspek sosial berada pada kategori tidak positif dengan persentase $33 \%$. Konsep diri berkaitan dengan aspek sosial yang dimiliki siswa belum dapat dikatakan bagus. Sebagian besar siswa memiliki perasaan yang negatif tentang kualitas hubungannya dengan orang lain Dengan temuan penelitian ini hendaknya guru BK di sekolah menyusun program palayanan BK yang dapat membangun dan mengembangkan konsep diri siswa dalam aspek sosial, melalui berbagai bentuk layanan seperti layanan informasi, penguasaan konten dan bimbingan kelompok. Diharapkan kegiatan tersebut mampu mengembangkan konsep diri sosial siswa kearah yang lebih positif.

\section{5) Kognitif}

Konsep diri siswa di SMAN 1 Lubuk Sikaping pada aspek kognitif berada pada kategori cukup positif dengan persentase sebesar 37\%. Dapat dipahami bahwa sebagian siswa belum mampu memahami dan menilai kemampuan dirinya sendiri secara positif dan objektif.

Berdasarkan hasil penelitian, guru BK diharapkan mampu berperan aktif dan menyusun program serta rencana pelaksanaan layanan BK yang dapat membantu siswa dalam mengembangkan konsep dirinya dalam aspek kognitif. Seperti pembentukan kelompok belajar dan penempatan siswa di kelas dengan merata. Selain itu guru BK hendaknya melaksanakan pelayanan BK yang sesuai dengan keadaan siswa dan mampu membangun konsep diri siswa yang positif dalam aspek kognitif.

\section{Prososial Siswa}

\section{a. Bentuk Umum Prososial Siswa di SMAN 1 Lubuk Sikaping}

Hasil penelitian menunjukkan rata-rata siswa SMAN 1 Lubuk Sikaping memiliki tingkah laku prososial cukup baik dengan persentase sebesar 64\%. Pencapaian skor prososial terbanyak berada pada aspek positif dengan total persentase $51 \%$. Namun pada sisi negatif masih terdapat siswa dengan total persentase $44 \%$. Artinya, sebagian siswa SMAN 1 Lubuk sikaping telah memiliki kemampuan untuk membangun dan menampilkan tingkah laku sosial yang positif dan baik, 
nampur sebagian lainnya masih ada yang belum mampu menampilkan prilaku prososial yang baik.

Menurut Elida Prayitno (2002: 140) gangguan konsep diri dan emosi akan menyebabkan terjadinya tingkah laku menyimpang, baik itu tingkah laku yang merusak diri sendiri, merusak kehidupan orang lain, atau pun tingkah laku merusak lingkungan alam sekitar. Hal ini tentu saja bertentangan dengan tingkah laku prososial yang merupakan segala bentuk tingkah laku atau rangsangan terhadap lingkungan dan situasi tertentu yang dapat memberikan kesejahteraan, kebahagiaan atau keuntungan bagi orang lain atau objek pertolongan.

Peranan konselor/guru BK akan sangat membantu jika konselor/guru BK turut aktif dalam mencegah terjadinya tingkah laku menyimpang dan memupuk tingkah laku prososial pada diri siswa asuhnya. Guru BK diharapkan mampu mengembangkan perannya dalam melaksanakan berbagai kegiatan layanan BK dan membimbing siswa agar siswa mampu menampilkan perilaku yang sesuai dengan nilai-nilai dan norma yang berlaku serta menguntungkan tidak hanya bagi dirinya sendiri, tapi juga orang lain dan lingkungan disekitarnya. Hal yang perlu dilakukan oleh guru BK adalah membimbing, mengarahkan serta menciptakan suasana dan hubungan sosial yang hangat dengan siswa melalui pelayanan BK dalam upaya pengembangan diri pribadi dan sosialnya. Guru BK diharapkan juga mampu menjadi model bagi siswa, sehingga prososial siswa akan semakin baik dan siswa mampu menampilkan perilaku sesuai dengan yang diharapkan.

\section{b. Prososial Siswa di SMAN 1 Lubuk Sikaping Pada Setiap Aspek \\ 1) Berbagi}

Berdasarkan hasil penelitian tergambar bahwa Prososial siswa di SMAN 1 Lubuk Sikaping pada aspek berbagi berada pada kategori baik, dengan persentase $33 \%$. Berbagi yang dimaksud adalah kesediaan untuk ikut merasakan apa yang dirasakan orang lain dalam suasana suka dan duka (Mussen dalam Adria, 2007: 35). Berdasarkan perolehan data dari hasil penelitian yang menunjukkan bahwa sebagian siswa telah memiliki prososial yang baik dan sebagian lagi masih ada yang memiliki prososial yang kurang baik. Maka dari itu, guru BK hendaknya berupaya untuk mempertahankan dan mengembangkan program dan layanan yang dapat membuat prososial siswa dalam aspek berbagi semakin baik dan tidak merosot.

\section{2) Menolong}

Hasil penelitian prososial siswa di SMAN 1 Lubuk Sikaping pada aspek menolong, menggambarkan bahwa pencapaian prososial siswa SMAN 1 Lubuk Sikaping terbanyak berada pada kategori baik dengan total persentase sebesar 32\%. Menurut Panner, dkk (2005: 367) menolong adalah tindakan untuk memberikan atau menawarkan bantuan kepada orang lain yang dilakukan dengan sukarela. Merujuk pada hasil penelitian yang menunjukkan bahwa prososial siswa dalam aspek menolong masih tergolong baik, maka dibutuhkan peran penting guru BK dalam mengembangkan program dan layanan yang dapat membantu siswa mempertahankan tingkah laku prososial pada aspek menolong yang sudah bagus dan meningkatkan tingkah laku prososial siswa yang masih belum baik. Setiap tingkah laku baik yang ditampilkan oleh siswa hendaknya diberikan reinforcement berupa pujian atau penghargaan, diharapkan siswa akan mengulang kembali tingkahlaku positif tersebut hingga menjadi suatu kebiasaan dalam kehidupan sehari-harinya.

\section{3) Kerja Sama}

Dari hasil penelitian, pencapaian prososial siswa di SMAN 1 Lubuk Sikaping pada aspek kerja sama, terbanyak berada pada kategori baik dan kurang baik dengan persentase sebesar 
$32 \%$. Menurut Mussen (dalam Adria, 2007: 35) yang dimaksud dengan kerjasama adalah kesediaan untuk melakukan pekerjaan atau kegiatan secara bersama-sama dengan orang lain demi tercapainya suatu tujuan. Hasil penelitian menunjukkan bahwa sebagian siswa telah mampu menampilkan perilaku kerja sama yang baik dengan sesamanya, namun di sebagian siswa lain menilai bahwa dirinya tidak mampu berkerja sama dengan orang lain, maka dari itu dibutuhkan peran penting guru BK dalam mengembangkan program dan layanan yang dapat membantu mempertahankan prososial siswa pada aspek kerja sama yang pada dasarnya sudah baik serta meningkatkan lagi pelayanan bagi siswa yang prososialnya tergolong masih kurang baik sehingga dapat lebih berkembang ke arah yang lebih positif. Dalam pelaksanaan layanan dapat diselingi dengan permainan-permainan ringan dan menghibur yang dapat melatih kerjasama siswa.

\section{4) Bertindak Jujur}

Hasil penelitian menggambarkan rata-rata prososial siswa di SMAN 1 Lubuk Sikaping pada aspek bertindak jujur berada pada kategori kurang baik dengan persentase sebesar 32\%. Hasil penelitian menunjukkan bahwa sebagian siswa belum mampu menampilkan tingkah laku apa adanya dan tidak mampu menahan diri untuk berbuat curang terhadap orang lain, meskipun sebagian siswa yang lain ada yang telah mampu menampilkan perilaku bertindak jujur dalam kehidupan sehari-harinya.

Berdasarkan kenyataan yang terjadi dilapangan perlu adanya pembinaan dan pengarahan dari orang tua, guru dan personel sekolah lainnya dalam upaya meningkatkan perilaku prososial siswa terutama dalam aspek bertindak jujur. Pihak-pihak terkait yang berada di sekitar siswa tentunya sangat perlu untuk memposisikan diri dalam mengatasi dan membimbing siswa dalam menampilkan perilaku.

\section{5) Berderma}

Hasil penelitian menunjukkan pada umumnya prososial siswa di SMAN 1 Lubuk Sikaping pada aspek berderma terkategori kurang baik dengan persentase sebesar $31 \%$. Berderma adalah kesediaan untuk memberikan secara sukarela sebagian barang miliknya kepada orang lain (Mussen dalam Adria, 2007:35). Hasil penelitian yang menunjukkan bahwa prososial siswa dalam aspek berderma tergolong baik, maka dibutuhkan peran penting guru BK dalam mengembangkan program dan layanan yang dapat membantu siswa mempertahankan dan lebih meningkatkan lagi tingkah laku prososial dalam aspek berderma. Guru BK perlu memberikan informasi dan pemahaman terhadap siswa bahwa berderma merupakan perilaku sosial positif yang dapat menguntungkan bagi orang lain.

\section{6) Memperhatikan Kesejahteraan \\ Orang Lain}

Hasil penelitian menggambarkan pada umumnya prososial siswa di SMAN 1 Lubuk Sikaping pada aspek memperhatikan kesejahteraan orang lain berada pada kategori kurang baik, dengan total persentase sebesar $35 \%$. Hasil penelitian menunjukkan bahwa prososial siswa pada aspek memperhatikan kesejahteraan orang lain tergolong kurang baik, artinya kebanyakan siswa belum mampu menunjukkan kepedulian terhadap permasalahan yang dialami oleh orang lain, meskipun sebagian yang lain masih ada yang sudah. Maka dalam hal ini guru BK diharapkan mampu berperan aktif dalam membimbing dan membina siswa dengan melaksanaan layananlayanan BK di sekolah dalam pengembangan diri pribadi dan sosial, seperti layanan informasi dan penguasaan konten agar siswa dapat menjadi pribadi yang peka dan peduli terhadap orang lain serta permasalahan yang terjadi disekitarnya. 


\section{Hubungan Konsep Diri dengan Prososial Siswa di SMAN 1 Lubuk Sikaping}

Setelah melakukan analisis uji korelasi dengan menggunakan program komputer SPSS (Statistic Product and Service Solution) for Windows release 16,0. atau menggunakan rumus Korelasi Pearson Product Moment, hasil yang diperoleh dari pengajuan hipotesis mengungkapkan bahwa terdapat hubungan yang signifikan positif antara konsep diri dengan prososial siswa di SMAN 1 Lubuk Sikaping. Hasil tersebut dibuktikan dengan angka koefisien korelasi $r_{\mathrm{xy}}=0,996$ dengan sig $=0,000$ $(\operatorname{sig}<0,01)$. Angka tersebut membuktikan bahwa terdapat hubungan yang signifikan bernilai positif antara variabel konsep diri dengan prososial siswa. Dapat dikatakan bahwa tingkat korelasi berada pada kategori sangat kuat. Hal ini menunjukkan semakin positif konsep diri siswa, maka prososialnya semakin baik. Sebaliknya, semakin negatif konsep diri siswa maka prososialnya akan semakin kurang baik.

Hasil temuan ini menguatkan pendapat Elida Prayitno (2006:86) yang menyatakan bahwa konsep diri remaja mempengaruhi tingkah laku sosialnya karena kesan tentang diri sendiri akan diproyeksikan dalam tingkah lakunya terhadap orang lain. Remaja yang memiliki konsep diri positif akan mampu menjalankan perannya dalam masyarakat dengan baik, dan cenderung menampilkan tingkah laku sosial yang positif.

Berdasarkan penjelasan di atas, dapat disimpulkan bahwa siswa yang mampu menilai dan memandang dirinya dengan positif memiliki kecenderungan menampilkan perilaku prososial yang baik di sekolah, demikian juga sebaliknya siswa yang tidak memiliki persepsi dan sudut pandang positif terhadap dirinya cenderung tidak menunjukkan perilaku prososial yang baik di lingkungan sekitarnya.

Dalam menyikapi keadaan ini, bimbingan dan konseling di sekolah memiliki peran yang sangat penting dalam membantu siswa membina dan membangun konsep diri yang positif pada diri siswa. Guru BK di sekolah diharapkan mampu menyusun program yang optimal dalam meningkatkan pemahaman positif siswa akan dirinya dan menunjukkan perilaku prososial kepada siswa lain maupun lingkungan sekitarnya.

\section{KESIMPULAN DAN SARAN}

\section{A. KESIMPULAN}

Berdasarkan hasil penelitian dan pembahasan mengenai konsep diri dengan prososial siswa, maka dapat disimpulkan:

1. Secara umum hasil penelitian menggambarkan rata-rata siswa di SMAN 1 Lubuk Sikaping telah memiliki konsep diri yang terkategori cukup positif.

2. Secara umum hasil penelitian juga mendeskripsikan bahwa rata-rata siswa di SMAN 1 Lubuk Sikaping memiliki prososial yang baik.

3. Terdapat hubungan yang signifikan positif antara konsep diri dengan prososial siswa di SMAN 1 Lubuk Sikaping, dengan tingkat hubungan korelasi berada pada kategori sangat kuat.

\section{B. SARAN}

Berdasarkan hasil penelitian yang telah dipaparkan sebelumnya maka dapat dikemukakan saran sebagai berikut:

1. Sesuai dengan hasil penelitian, secara umum konsep diri dan prososial siswa di SMAN 1 Lubuk Sikaping berada pada kategori cukup positif dan cukup baik, artinya sebagian siswa telah memiliki konsep diri yang positif dan menampilkan prososial yang baik, namun sebagian siswa lainnya masih memiliki konsep diri yang tidak positif dan prososial yang tidak baik. Maka dari itu, guru BK diharapkan memberikan pelayanan bimbingan dan konseling di SMAN 1 Lubuk Sikaping yang bersifat preventif bagi siswa yang 
konsep diri dan prososialnya telah positif dan baik, yang bertujuan agar konsep diri positif yang telah dimiliki siswa dapat dipertahankan. Selanjutnya untuk sebagian siswa lainnya yang masih memiliki konsep diri negatif dan menampilkan perilaku prososial yang kurang baik, diharapkan kepada guru BK agar dapat melaksanakan layananlayanan BK yang bersifat kuratif, untuk membantu siswa menyelesaikan permasalahan yang dihadapinya terutama mengenai konsep diri dan prososial, contohnya layanan informasi tentang membangun konsep diri yang positif, sehingga konsep diri siswa dapat berkembang ke arah yang lebih positif dan siswa mampu menampilkan tingkah laku prososial yang lebih baik. Guru BK diharapkan mampu berperan aktif dalam meningkatkan perilaku prososial siswa di sekolah, dengan cara selalu meningkatkan pengetahuan, pengalaman dan wawasannya untuk meningkatkan kualitas pelayanan Bimbingan dan Konseling, khususnya mengenai konsep diri dan tingkah laku prososial siswa.

2. Diharapkan kepada pihak sekolah dan guru agar dapat berkerjasama dengan orang tua dalam rangka membangun dan mengembangkan konsep diri siswa yang pada dasarnya sudah positif, sehingga perilaku prososial yang baik pun dapat dipertahankan. Sedangkan untuk meningkatkan prososial siswa yang masih berada pada kategori kurang baik, perlu adanya koordinasi dalam menyikapi tingkah laku dan keseharian siswa baik di lingkungan sekolah, masyarakat dan terutama di lingkungan keluarga.

3. Bagi peneliti selanjutnya, penelitian ini masih jauh dari kesempurnaan, direkomendasikan penelitian ini agar dapat dilanjutkan dan dikembangkan dalam aspek-aspek lain yang berkemungkinan dapat mempengaruhi tingkah laku prososial siswa.

\section{KEPUSTAKAAN}

Agus Abdul Rahman. 2012. Psikologi Sosial: Mengintegrasikan

Pengetahuan Wahyu dan Pengetahuan Empirik. Bandung: UIN Bandung.

Alex Sobur. 2011. Psikologi Umum dalam Lintasan Sejarah. Bandung: Pustaka Setia Bandung.

Bimo Walgito. 2003. Psikologi Sosial (Suatu Pengantar). Yogyakarta: Andi Offset.

Burns. 1993. Konsep diri (Teori Pengukuran. Perkembangan dan Perilaku). (Alih Bahasa:Eddy). Jakarta: Arca.

Elida Prayitno. 2006. Psikologi Perkembangan Remaja. Padang: Angkasa Raya..

Elizabeth B, Hurlock. 1980. Psikologi Perkembangan. Jakarta: Erlangga.

Mudjiran, dkk. 2002. Perkembangan Peserta Didik. Padang: UNP.

Sarlito Sarwono dan Eko A. Meinarno. 2009. Psikologi Sosial. Jakarta: Salemba Humannika

Shelley, dkk. 2009. Psikologi Sosial. Jakarta: Kencana

Suharsimi Arikunto. 1998. Prosedur Penelitian. Jakarta: Rineka Cipta.

Riduwan. 2009. Metode dan Teknik Menyusun Tesis. Bandung: Alfabeta. 